\title{
The vulnerability of agricultural and livestock systems to climate variability: using dynamic system models in the Rancheria upper basin (Sierra Nevada de Santa Marta)
}

\section{Cesar Augusto Ruiz-Agudelo, Oscar David Bonilla-Uribe \& Carlos Andres Páez}

Keywords: Sierra Nevada de Santa Marta, Colombia, biosphere reserve, Rancheria upper basin, climate variability, drought sensitivity, modelling of dynamic systems, farming, vulnerability

\section{Abstract}

Profile

When you are defining the vulnerability of mountain ecosystems it is vital to identify production systems that may collapse because of climate change or land degradation. This study explores these challenges by analysing the effect of a range of external pressures on the vulnerability of agricultural systems in the upper basin of the Rancheria River (Sierra Nevada de Santa Marta Biosphere Reserve [BR], Colombia). Models of dynamic system approaches were made to understand how communities became vulnerable to global change. We evaluated the change in external pressures, such as the ability of different agro-ecosystems to tolerate climate variability, the ability of rural communities to adapt to climate variability based on their access to resources, and the institutions and policies to deal with the crisis of socio-political governance. Existing ecological and participatory research findings were reassessed along with data gathered from farming activities. We followed an iterative process explaining how external drivers led to changes in agro-ecosystem resilience, access to resources and the ability of institutions to buffer the system. Causal loop diagrams and statistical dynamic system models were used to express key quantitative relationships. Future scenarios were created to determine areas of concern most sensitive to change. Certainly the more land management knowledge and practices are shared between private and community land managers the more win-win benefits will be available to reduce system vulnerability, increase income and build social capital.

Protected area

\section{Sierra Nevada de}

Santa Marta Biosphere

Reserve

Mountain range

Andes

Country

\section{Colombia}

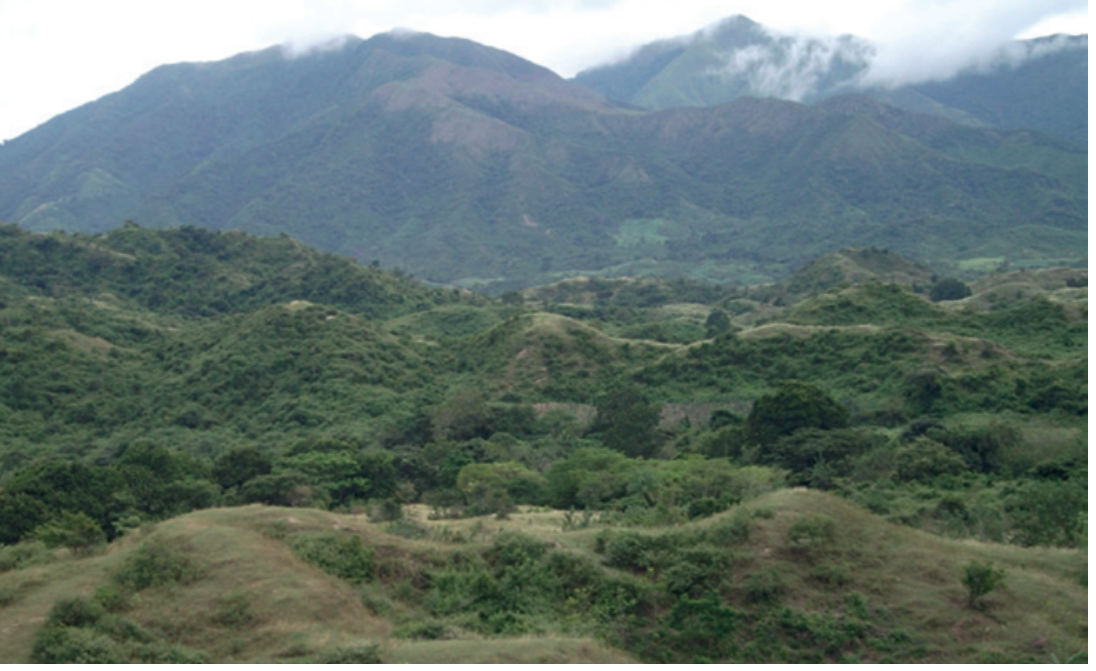

Figure 1 - Production systems in the Rancheria upper basin. (C) C. Ruiz. (2013)

\section{Introduction}

The area of study is the upper basin of the Rancheria River. The UNESCO BR stretches across 2.1 million ha and includes Tayrona National Park (56250 ha) and Sierra Nevada de Santa Marta National Park (675000 ha). This research focuses on agricultural systems (climatically marginal dry lands and receivers of ecosystem services), which have experienced frequent droughts (IPCC 2007; Santibáñez \& Santibáñez 2007; FAO 2009). Furthermore, agricultural societies have been confronted with a variety of changes in their farming systems (Toro et al. 2012; Feola 2013), partly because of the land tenure reform which disrupted traditional agricultural management (Montero et al. 2011).

Climate change is expected to have widespread impacts on agro-ecological systems, particularly in the tropics (Battisti \& Naylor 2009). For example, in Colombia, agricultural systems and adaptation responses will critically affect farmers' livelihoods (Eslava \& Pabon 2001; Ramirez et al. 2012; Machovina \& Feeley 2013; Ramirez \& Khoury 2013). Evidence of marked climate variability is manifest in the upper basin of the Rancheria (Lonin et al. 2010; CORPOGUAJIRA 2011; Ramirez \& Del Valle 2012; Villegas \& Khoury 2013).

According to the second communication of Colombia to the United Framework Convention on Climate Change - UNFCCC (IDEAM 2010), the Guajira is one of the regions in the country with major temperature increases, changes in precipitation and climate variability. Because of this it is important to develop integrated research based on global change and sustainability science (Reynolds et al. 2007). However, details of how best to conduct these studies are still being developed. 


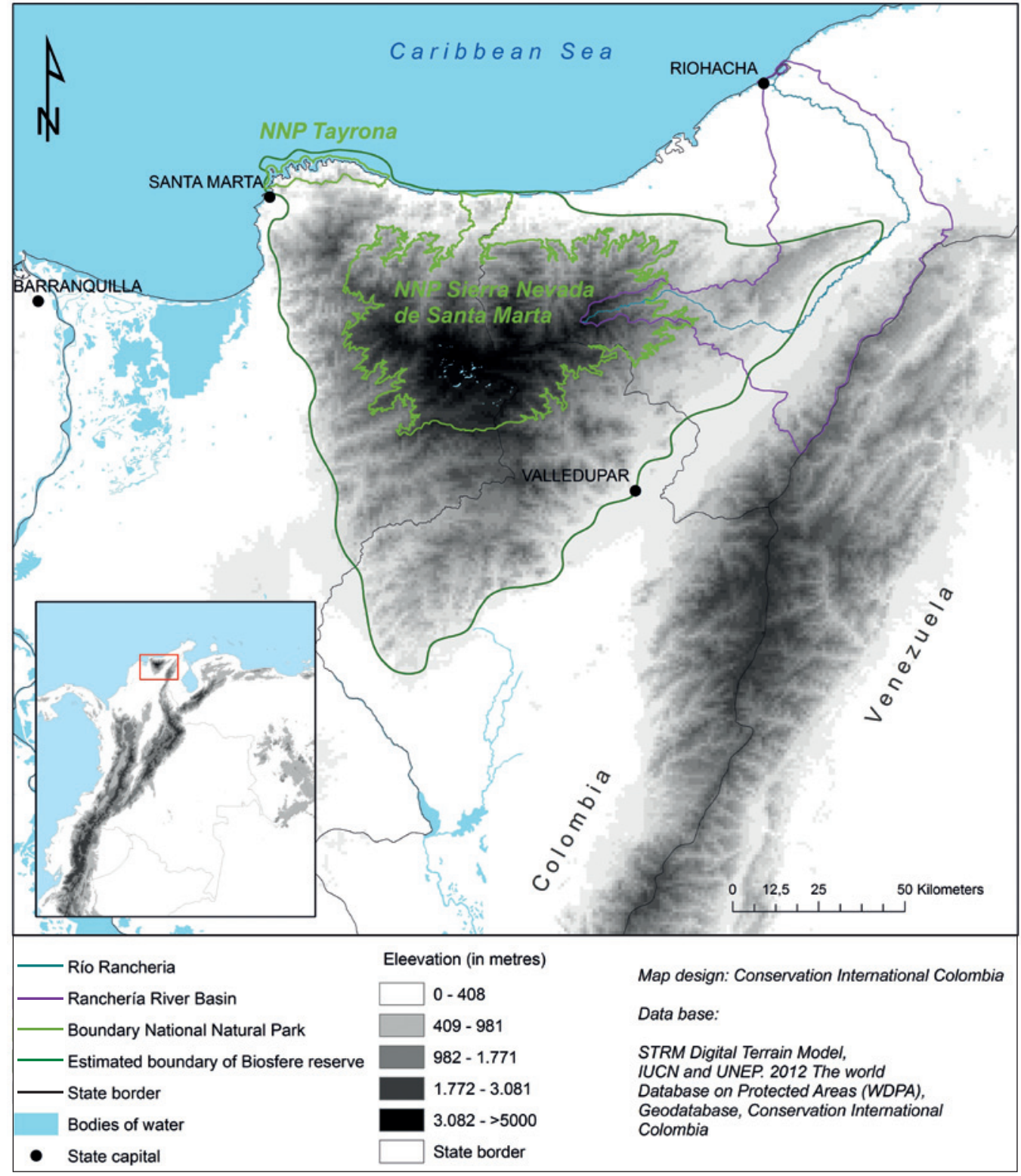

Figure 2 - Case study area

This research uses dynamic system models to understand the vulnerability of food systems to climate change and land degradation, focusing on their sensitivity to climate variability in the Rancheria upper basin. On this study we utilized published data, field ecological and participatory research findings to generalize factors that influence how agro-ecosystems respond to climate variability. These factors are associated with key components of the agricultural system using dynamic system models that evaluate a series of quantifiable future scenarios.

This paper is an empirical contribution to developing a detailed analysis of agricultural and livestock systems to answer two research questions: (1) Is there evidence that the agricultural and livestock food system in the Rancheria upper basin is becoming more vulnerable to climate variability? And (2) what policy leverage points exist to reduce vulnerability in these agro-ecosystems?
In addition, this paper offers a theoretical case study that helps evaluate the strengths and weaknesses of dynamic systems using quantitative modelling to assess an agricultural system's vulnerability in neotropical ecosystems. Up to now livelihood research has been based on field research conducted mostly in other regions, e.g. Africa (Dougill et al. 2010; Sendzimir et al. 2011). Some contributions on Colombia have been made by Muggah (2000), González \& Lopez (2007), Borsdorf (2011) and Tovar \& Irazábal (2014) in relation to internal conflict, political violence, displacement, climate change and social sustainability of production systems. Marchant \& Borsdorf (2013) have also written on the sustainability production systems in the Sierra Nevada de Santa Marta (Biosphere Reserve). However, quantitative modelling that links socioeconomic and biological factors has not been presented to date. 

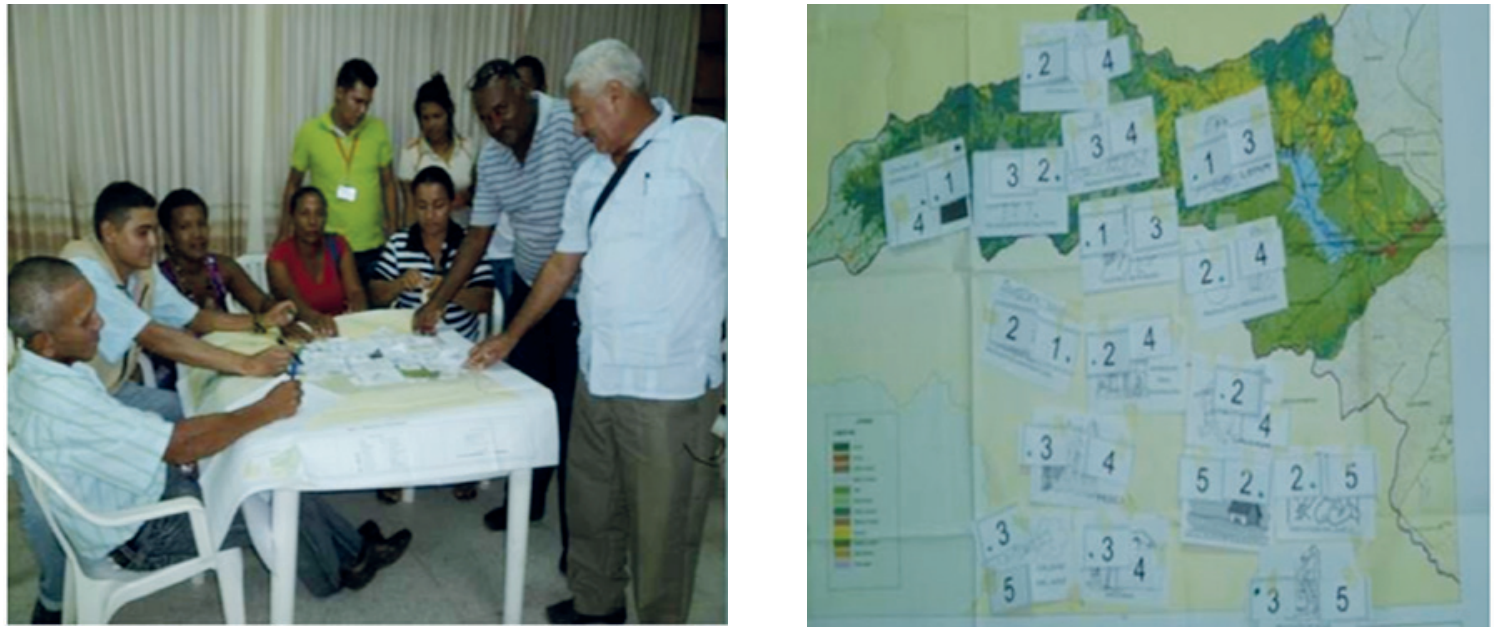

Figure 3 - Participatory assessment of ecosystem services with smallholder farmers. C C. Ruiz. (2013)

\section{Study area}

The department of La Guajira (Figure 2) is located in the northernmost part of Colombia, on a peninsula, bordering in the south on the Sierra Nevada de Santa Marta (CORPOGUAJIRA 2011: 9 T2). La Guajira is the largest national producer of salt, gas and coal, and it is also the department with the highest number of cattle and goats in the country, yet its economy is one of the smallest (CORPOGUAJIRA 2011: 255 T2). The specific area of study is the upper basin of the Rancheria River. It has an area of 41391 ha and covers the municipalities of San Juan del Cesar, Distracción and Fonseca.

The Rancheria River begins at the Chirigua Páramo, which is located in the eastern flank of the sierra at an altitude of $3875 \mathrm{~m}$. The temporal variability in the water supply of the Rancheria River is twice as high as the average variability of the country. Water supply is highly unstable, with a high risk of drought and flood and a high rate of evaporation, especially in the upper basin (CORPOGUAJIRA 2011: 68 T3).

Two indigenous societies and rural settlers (farmers) cohabit in the Rancheria upper basin: the ethnic groups of the Wiwa and the Kogi. Indigenous groups have communal properties, while farmers own land individually. According to Ruiz et al. (2013: 26, 57) the main agricultural production in the area is cassava, followed by corn, taro, pasture, bananas and coffee. Pastures cover the largest area $(62 \%)$, corn the smallest at $11 \% .91 \%$ of farmers use traditional techniques such as slash-and-burn, while $83 \%$ of the land is used for livestock practices, with poultry the most common (chickens), followed by cattle and pigs (see Figure 1).

\section{Methods}

In this study we used the techniques of observation, mapping, literature and document analysis, data analysis, expert interviews, standardized surveys and satellite image analysis. We also developed six meth- odological steps, which took us from the initial integration of local and scientific knowledge to a quantitative vulnerability analysis and enabled us to model different management alternatives, market options and policy issues in two future scenarios:

1. We developed workshops with local people (Figure 3) to understand local perceptions of environmental problems, ecosystem services conflicts, environmental change and the vulnerability of livelihoods (Emerton \& Mogaka 2001; Ruiz et al. 2013: 60, 63).

2. We consulted a range of professional and local experts who have conducted ecological and socioeconomic studies in the region for more than five years and who have been developing conceptual models of how agro-ecosystems work (Ruiz et al. 2013: 63, 82). This was accompanied by the evaluation of land-user interview transcripts to obtain a narrative background which provided social, institutional and ecological contexts of the livelihood systems.

3. We used local economic, agricultural and livestock data to establish the conceptual model of the system, focusing on three dimensions of vulnerability: agro-ecological vulnerability, household assets and institutional factors (Fraser 2007).

4. We then used Vensim modelling software (Ventanna Systems, Inc.) to create causal loop diagrams to examine how ecological, economic and socio-political factors might have interacted to generate these reference modes and influence the dynamics of resilience in the Rancheria upper basin. Two models were constructed, one for communal lands and another for private lands.

5. We applied the Fraser conceptual framework (Fraser 2007) to examine how resilience dynamics are reflected in the course of the Rancheria upper basin in the three-dimensional space bounded by the ecological, economic and socio-political domains.

6. The last quantitative step in this process aimed at understanding the nature and strength of the relationships. We will explicitly discuss the value of this key aspect and its potential consequences. 

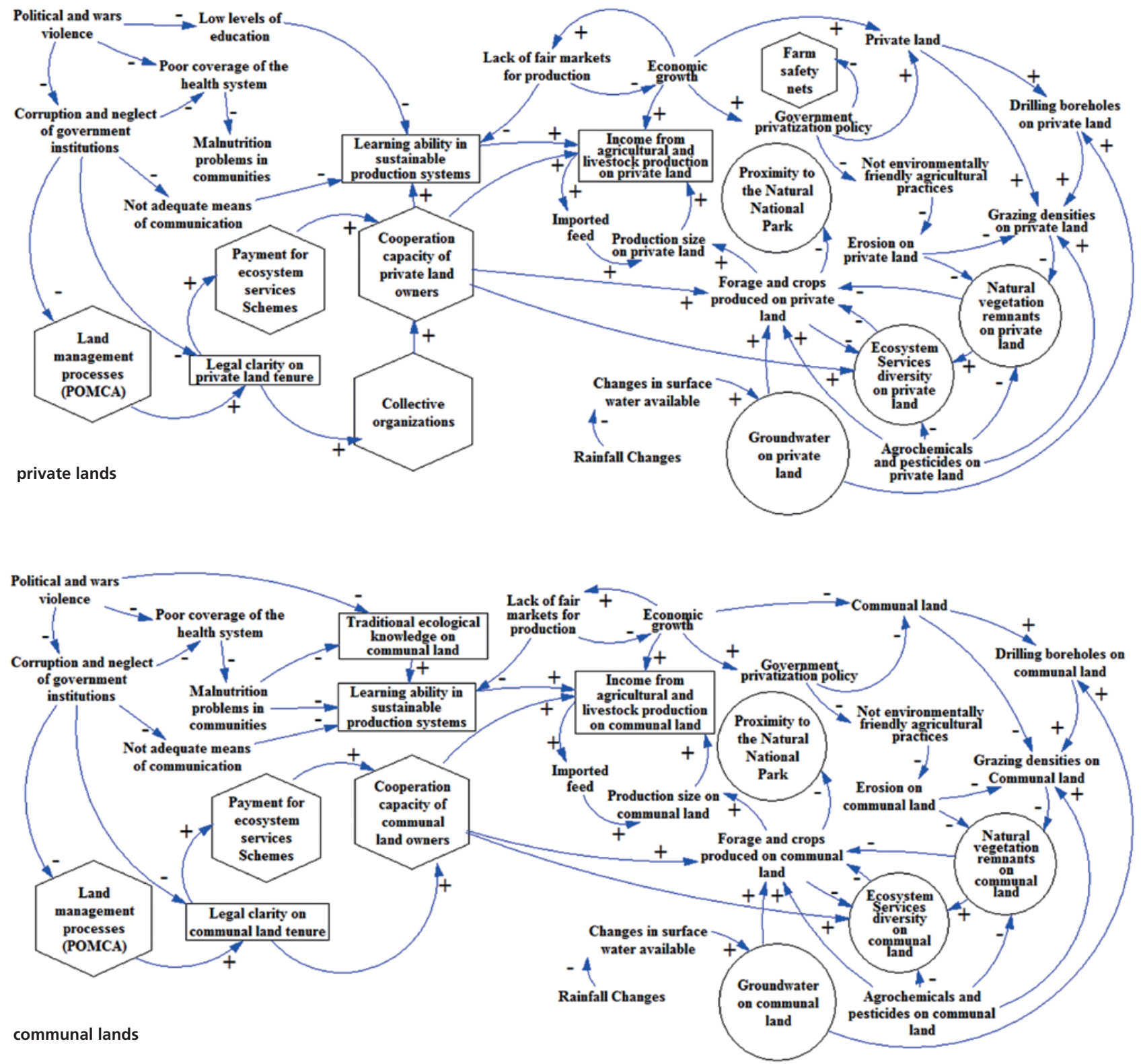

Figures 4 (top) \& 5 (bottom) - Dynamic systems model of the agricultural and livestock system of Rancheria upper basin on private lands (Figure 4) and communal lands (Figure 5). The sign next to each arrow (+ or -) indicates whether the relation is positive or negative, based on interviews and / or available data analysis. Circles: variables refer to the ability of the agro-ecosystem to remain productive during climate variability events ( $x$-axis of Figure 7). Boxes: variables inside boxes refer to the ability of individuals to adapt to climate variability events (y-axis of Figure 7). Hexagons: variables in hexagons refer to the feasibility for the design and implementation of collective solutions to adapt to climate variability events, based on institutional faculties, family, social and kinship networks (z-axis of Figure 7). Open text: identifies drivers of system changes

\section{Results and discussion}

\section{Conceptual model}

A series of 24 one-on-one interviews were held with experts who have worked extensively on agricultural and livestock systems in the study region. From these interviews we developed a more holistic conceptual model of the farming systems and identified socioeconomic, environmental and political drivers of change, which draw on ecological research outputs and interviews undertaken with farmers, extension workers and policy makers (CORPOGUAJIRA 2011: 39 T5; Ruiz et al. 2013: 100).
After these interviews, two workshops were conducted with experts who have worked in these livelihood systems (Ruiz et al. 2013: 168). During the workshops the conceptual models were presented. The background narrative was turned into a dynamic systems model flow chart (Figures 4 and 5) which identifies the feedback loops and highlights indicators of vulnerability to be assessed in subsequent qualitative and quantitative analyses. 


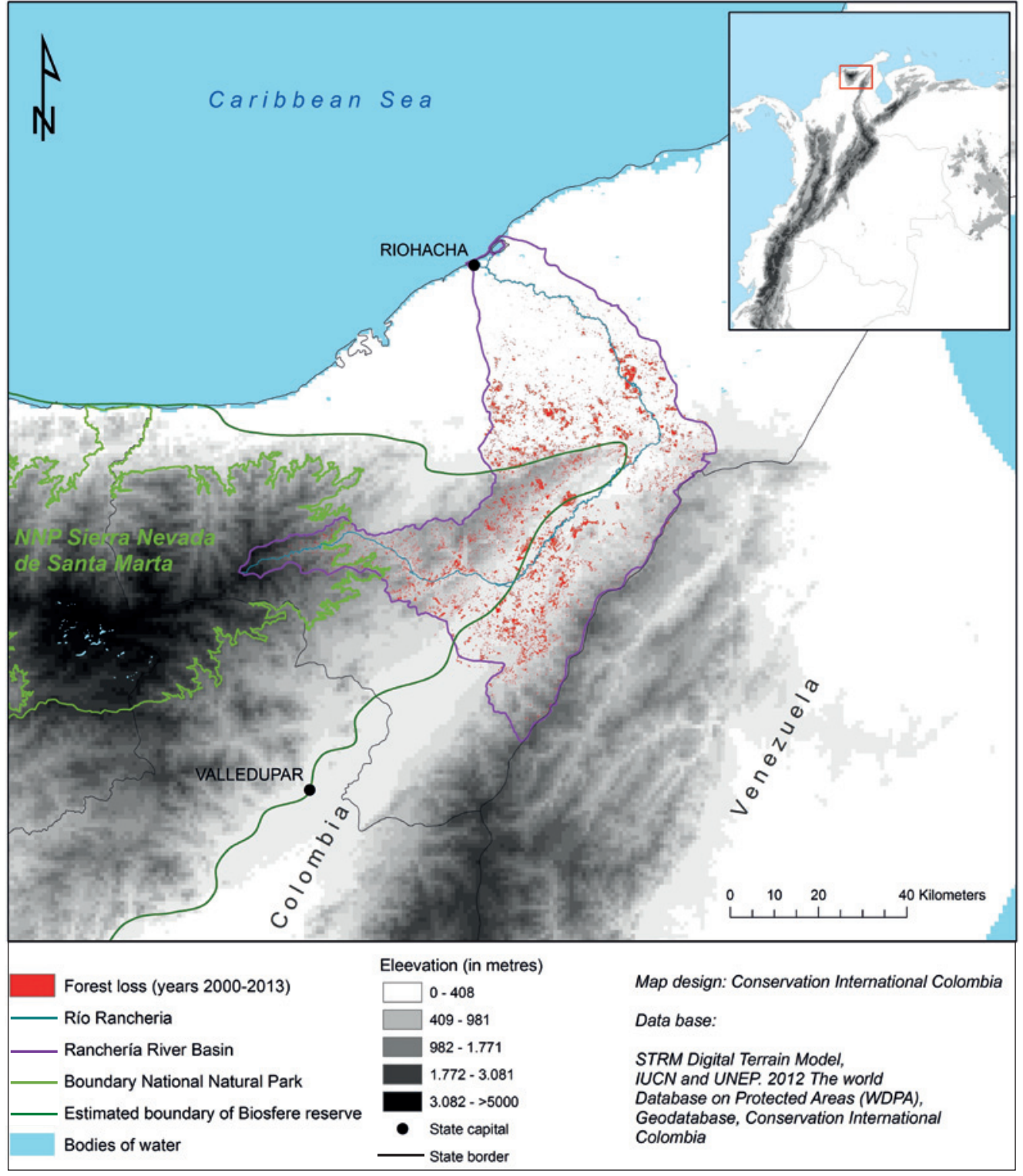

Figure 6 - Loss of natural land cover in the Rancheria basin (between 2000-2013)

\section{Qualitative approach}

\section{Agro-ecosystems}

In terms of the ability of agro-ecosystems to remain productive during the effects of climate variability (variables within the circles of Figures 4 and 5), a series of major environmental changes suggests that the Rancheria upper basin is losing its agro-ecological resilience:

1. Reduction in the natural cover and replacement by grasses (Figure 6): A multitemporal analysis of changes in coverage between 2000 and 2013 reveals the trend to loss of natural cover in the Rancheria basin (37\% forests and $63 \%$ other natural land cover).

2. Increased spatial heterogeneity and a decrease in the aggregation ability of essential soil nutrients $(\mathrm{N}$ and $\mathrm{P}$ ): This phenomenon is associated with grazing patterns and intensive agriculture with external inputs; e.g. agrochemicals and pesticides (CORPOGUAJIRA 2011: 208 T2; Ramirez \& Khoury 2013; Ruiz et al. 2013: 58).

3. Decrease of key ecosystem services for agricultural and livestock production, such as water regulation, water quality and sediment retention (Robards et al. 2011; Ruiz et al. 2013: 67).

4. Climate variability (IDEAM 2010: 81,87, 88; CORPOGUAJIRA 2011: 102 T3).

5. Borehole water depths are increasing and very little potable water is currently found (CORPOGUAJIRA 2011: 105 T3) generating greater pressure on water resources.

6. These changes could threaten the resilience of agro-ecosystems in the Rancheria upper basin. The inhabitants are seeking alternative livelihood options, ranging from migration to urban centres to increased dependence on government support, for example, subsidies and disaster relief for detrimen- 


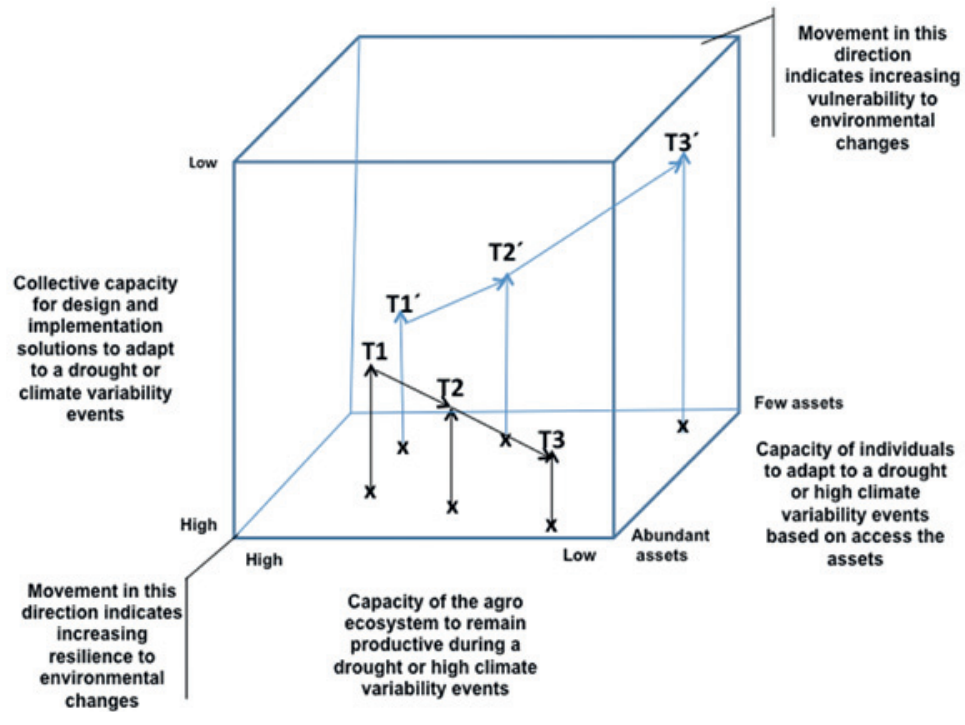

Figure 7 - Heuristic depiction of changing levels of vulnerability to climate variability for Rancheria upper basin farmers over the past 20 years. T1, T2, and T3 refer to wealthy farmers on private lands. T1', T2' and T3' refer to less affluent farmers on communal lands. Vulnerability to climate variability framework based on three key scales (agro-ecological, livelihoods and institutional). Movement over time towards the top, back, right-hand corner indicates increased vulnerability. tal climate effects (Muggah 2000). The inefficiency of these support systems as a result of government corruption, plus reduced access to regional markets, further threaten the viability of local communities (Montero et al. 2011; Tovar \& Irazábal 2014).

\section{Individuals}

In terms of the ability of individuals to adapt to climate variability (variables within boxes in Figures 4 and 5), communities across the Rancheria upper basin span a range of ethnic groups, principally Kogi, Wiwa, Arhuaco and farmers / settlers, with different cultural histories (CORPOGUAJIRA 2011, 15 T5; Polo 2011). These differences make it difficult to generalize about the socioeconomic nature, cultural dynamics and community structure (Gómez-Baggethun et al. 2013). The Kogi-Wiwa are the dominant ethnic group, who introduced cattle and slash-and-burn practices in agriculture over 300 years ago. At present farmers and settlers make up the majority of the population of the Rancheria upper basin.

Communal lands (indigenous reservations) have legal and tenure characteristics which differ from private lands. The Kogi-Wiwa people are hierarchical societies with strong traditional community structures and a collective property of the land. The traditional authority has declined despite being recognized in Colombian law (Act 21 of 1991). At the same time farmers and settlers populate the private lands (near to the WiwaKogi reservations); these social groups have less solid community structures, based on local action, farming and livestock networks. It should be noted that both communal and private lands have weak governance levels. In general their proficiency in political dealings (governance) and their ability to acquire sustainable production practices have declined very severely over the last 20 years (González \& Lopez 2007; CORPOGUAJIRA 2011: 15 T5).

Both social groups endure similar shortage situations and serious difficulties in accessing fair markets (for live- stock and agricultural products); this situation reduces income, exacerbates conflicts and increase pressures on land, water and other resources (CORPOGUAJIRA 2011: 15 T5; Ruiz et al. 2013: 91). Lack of access to fair markets decreases their revenue options and forces them to migrate to nearby cities; this increases the local agricultural systems vulnerability, especially for the indigenous groups (Gobernación de la Guajira 2012).

Corruption, inefficiency of state organizations, low levels of education and the deterioration of the regional health systems are drivers that, along with a model of economic development which is unfavourable to sustainable agriculture production, affect the governance of territories. These complex situations encourage deforestation and landscape change (Gamarra-Vergara 2006; Koyuncu \& Yilmaz 2013).

\section{Collective capacity}

Actions for sustainable development at community level have become a key element of intervention to deal with many serious environmental problems. The collective ability of agricultural and livestock farming communities to respond to climate variability (variables within hexagons in Figures 4 and 5) is based on the effectiveness of formal or informal institutions, including social networks (Robards et al. 2011).

During the second half of the $20^{\text {th }}$ century their traditional indigenous systems and local rural institutions have been weakening; this situation is now recognized as a regional problem (CORPOGUAJIRA 2011: 26 T5). The formal participation process for defining local development plans (Environmental Management Plans - POMCA, Decree 1640 of 2012) that involve owners of communal and private lands in the management of resources (CORPOGUAJIRA 2011: 15 T6) and the implementation of collective financial instruments, such as the Payment for Ecosystem Services implemented for the Rancheria upper basin (Ruiz et al. 2013: 93), seek to strengthen cooperative capabilities and local networks of indigenous and farmers. These 
Table 1 - Summary of scenarios developed to quantify the relative effect of different drivers on the value of agricultural production for private and communal farmers in the Rancheria upper basin.

\begin{tabular}{|c|c|c|c|}
\hline Scenario & Description & Lower estimates & Upper estimates \\
\hline $\begin{array}{l}\text { Climate change and climate } \\
\text { variability }\end{array}$ & $\begin{array}{l}\text { This scenario determines the effect } \\
\text { climate variability has on the value } \\
\text { of communal and private agricul- } \\
\text { tural production, based on rainfall } \\
\text { projections and historical rainfall } \\
\text { patterns (IDEAM 2010). }\end{array}$ & $\begin{array}{l}35 \% \text { inter-annual variability and no } \\
\text { long-term change in rainfall. }\end{array}$ & $\begin{array}{l}35 \% \text { inter-annual variability and } \\
\text { a } 0.5 \% \text { p. a. decline in average } \\
\text { rainfall. }\end{array}$ \\
\hline Environmental management & $\begin{array}{l}\text { This scenario shows to what extent } \\
\text { best agricultural management } \\
\text { practices might reduce the effects } \\
\text { of natural vegetation changes, } \\
\text { based on the ecological literature } \\
\text { about the effects of natural vegeta- } \\
\text { tion changes. }\end{array}$ & $\begin{array}{l}\text { Improved management leads } \\
\text { to increases of } 1 \% \text { p. a. (of the } \\
\text { natural vegetation) for a period of } \\
10 \text { years on private land, whereas } \\
\text { improved management on com- } \\
\text { munal land leads to increases of } \\
0.5 \% \text { p. a. (of the natural vegeta- } \\
\text { tion) for a period of } 20 \text { year. }\end{array}$ & $\begin{array}{l}\text { Vegetation change leads to a } 0.5 \% \\
\text { p. a. decline over the full model } \\
\text { run period for both private and } \\
\text { communal farmers. }\end{array}$ \\
\hline $\begin{array}{l}\text { Policy frameworks for } \\
\text { sustainable family farming }\end{array}$ & $\begin{array}{l}\text { This scenario simulates the effects } \\
\text { of a national public policy that } \\
\text { slows the rate at which communal } \\
\text { and private land is changed. It is } \\
\text { based on the effects of a similar } \\
\text { policy in neighbouring countries } \\
\text { and regions. }\end{array}$ & $\begin{array}{l}\text { A slow conversion rate from com- } \\
\text { munal and private land of } 0.1 \% \\
\text { p. a. }\end{array}$ & $\begin{array}{l}0.5 \% \text { p. a. of communal and } \\
\text { private land is transformed, based } \\
\text { on the high rates of changes in } \\
\text { land use. }\end{array}$ \\
\hline Market conditions & $\begin{array}{l}\text { This scenario determines how } \\
\text { changes in the price of agricultural } \\
\text { products may affect the value of } \\
\text { communal and private agricultural } \\
\text { production, based on long-term } \\
\text { agricultural price trends. }\end{array}$ & $\begin{array}{l}5 \% \text { p. a. increase in the price of } \\
\text { agricultural products thanks to bet- } \\
\text { ter market access or higher market } \\
\text { prices (internationally or from } \\
\text { greater national control / price } \\
\text { guarantees to farmers). }\end{array}$ & $\begin{array}{l}15 \% \text { annual variability in price but } \\
\text { no long-term changes because } \\
\text { historic analysis of price does not } \\
\text { show significant rises or falls in } \\
\text { adjusted agricultural products price } \\
\text { over the past } 20 \text { years. }\end{array}$ \\
\hline
\end{tabular}

arrangements encourage local organizational processes, production management and adaptation to global environmental change.

\section{Vulnerability assessment models}

According to the analytical framework developed by Fraser (2007) and based on analysis of the literature, interviews and workshops conducted in the last five years, there are two broad vulnerability pathways (Figure 7):

- The first path is for affluent private farmers or those with more resources who have lost out in terms of ecological resilience, but gained in terms of collective and individual capacity to respond to climate variability.

- The other pathway is for the less affluent indigenous people, communal farmers who have seen their vulnerability increase in all three dimensions.

\section{Quantitative vulnerability assessment}

To express the quantitative vulnerability assessment, we have created forecasting scenarios, based on available knowledge and information. It is important to go through these mathematical steps, using best available estimates, to be able to quantify future scenarios. We determined whether the relationships were positive or negative (Figures 4 and 5) and their relative strength to model scenarios; we used data from the National Agricultural Survey (DANE 2012) on crop and livestock production. In addition we used this mix of expert insight and yield analysis to determine relationships and we also made estimates as to the slope of the different relationships.
We used these assumptions as the basis for a series of hypotheses and expressed these as simple equations that demonstrate how each variable was related. Once the model was expressed in this way, we generated a baseline scenario and different policy, management and market scenarios to see how sensitive the vulnerability to climate variability was for different interventions.

We developed four different scenarios based on: - the climate change scenarios for the region, based on national scenarios (IDEAM 2010);

- the agricultural management for reducing land degradation rates;

- the government policy that encourages sustainable agricultural production systems and rural development;

- the effects of changes in the price for agricultural and livestock products.

Each of these four scenarios were parameterized by creating a best-case and a worst-case situation that reflected the range of conditions deemed likely from the literature (Table 1). These best- and worst-case variants of each scenario were combined using the VENSIM software, giving 16 variants. The combinations of climate, land management, market and policy scenarios provide a range of plausible futures that allow modelling how overall system behaviour changes in response to these factors.

Because of limitations in data quality, these remain only general trends of financial performance data. The statistics about production and prices (at departmental and municipal levels) in particular show 

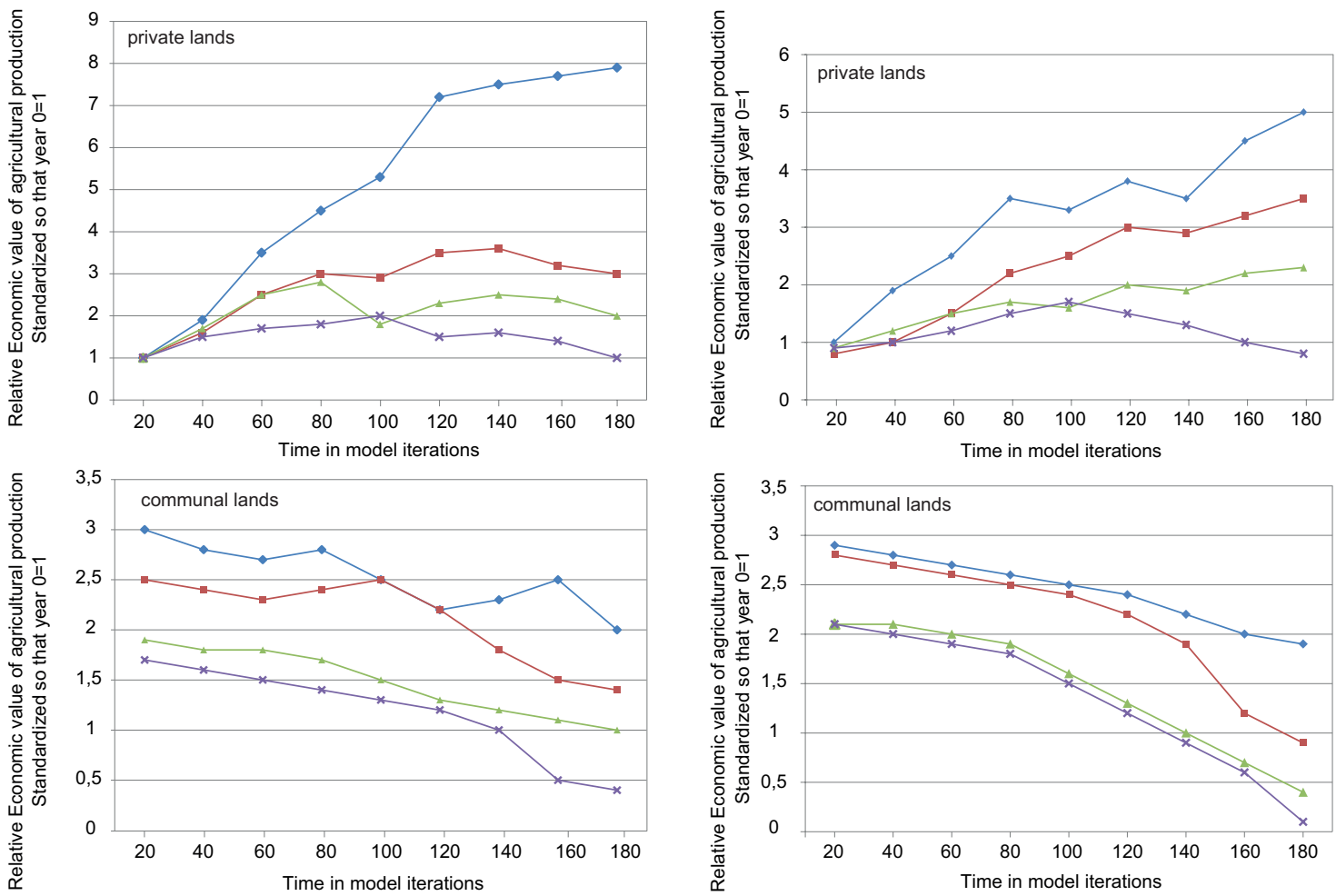

$\rightarrow$ Best management without climate change and climate variability - Land management without climate change and climate variability - Best management with climate change and climate variability

* Land management with climate change and climate variability

Figure 8 - Management scenario options and their impacts on the value of agricultural and livestock production on: private lands (top) and communal lands (bottom) as per scenario assumptions in Table 1

high inter-annual variability, which is difficult to capture in simplified market price scenarios on a larger scale (DANE 2012). This contribution focuses on income variations as a result of changes in the size of agricultural production, which is an indicator of an individual's ability to adapt to climate variability on a regional scale.

What are the key points that could reduce vulnerability of this socio-ecological system?

From the dynamic models we produced output graphs to demonstrate the effects of different management scenarios (Figure 8), market scenarios (Figure 9) and policy options (Figure 10). Figures 8 and 9 show the outputs of 180 iterations / year models of the total production and the relative economic value of agricultural production on private lands (Figures 8 top and 9 top) and communal lands (Figures 8 bottom and 9 bottom), under different scenarios of natural cover degradation and climate change. Figure 10 shows the effect on the total relative value of agricultural production on private and communal lands that would result from changes in the rate of land conversion. All of this should be possible with a policy on sustainable and environmentally friendly production.

Figure 9 - Market scenario options and their impacts on the value of agricultural and livestock production on: private lands (top) and communal lands (bottom) as per scenario assumptions in Table 1

From the modelling of future scenarios the following key issues emerge:

1. The effects of climate change, according to the predictions of the Intergovernmental Panel on Climate Change (IPCC) and the IDEAM (2010), will have the largest economic impact on the future value and economic viability of agricultural systems. Efforts made at local and regional levels (e. g. POMCA and PES) will not have so great an economic impact on the future as global climate variability.

2. The positive benefits of improved management of production systems, using sustainable farming and conservation practices, are a common factor in all the analysed cases. The effect of best management is greatest under private land ownership and for the first 80 years of modelled iterations, an indication that this scenario is capable of absorbing much of the economic effects associated with climate variability (Figure 8 top).

3. Simulated market growth scenarios are not sufficient to mitigate the economic losses expected on communal lands. This is because of the ongoing changes in the rates of natural land cover, the constant weakening of collective institutional pro- 


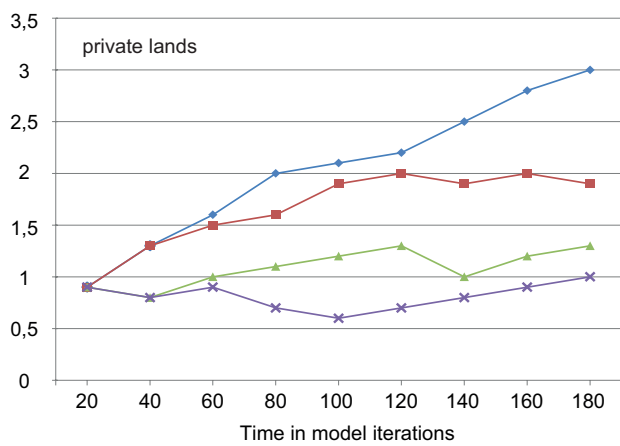

these production systems differently, despite their being located in the same climatic and ecological region. It is likely that agricultural production and its associated revenues will continue to decline in communal lands in most of the envisaged scenarios. This is due to the effects of land degradation, exacerbated by climate change, and the breakdown of collective cooperation systems and traditional knowledge. The lack of governance and the absence of realistic and feasible politics help to explain, from a public perspective, some of the difficulties to promote the necessary changes in agricultural production strategies.

The quantitative aspect of this study suggests that improving access to markets and strengthening the most impoverished farmers institutionally through management committees or formal community-based guilds could reduce the vulnerability of the system.

The models reveal that issues associated with climate variability are not considered in the current planning processes where land use is decided. These elements must be included to better understand regional vulnerability.

\section{Acknowledgements}

The authors wish to thank to Conservation International Colombia and the Autonomous Regional Corporation of Guajira (CORPOGUAJIRA) for funding this work. Thanks are also due to the farmers and indigenous communities who were such kind hosts and to the interviewed experts.

\section{References}

cesses and poor access to new technologies, which in turn further limit communal access to fair and competitive markets (Figure 9 bottom). Policy to support market prices for agricultural products would favour the private sector which is more efficient in producing for national and regional markets (Figure 9 top).

4. Policy interventions aimed at changing the rate of natural cover transformation on communal and private lands (e.g. incentives for conservation agriculture, cleaner production technologies, etc.), evaluated from a purely economic standpoint, could increase the value of agricultural land (Figure 10 top and bottom).

The modelling results represent only the financial effects expected of the different scenarios in relation to current agricultural systems. Therefore these results do not incorporate important effects on social capital, community cohesion, social equity, poverty levels and ecosystem services.

\section{Conclusions}

The differences in the future revenues of the private and communal lands underline the need to treat

Battisti, D.S. \& R.L. Naylor 2009. Historical warnings of future food insecurity with unprecedented seasonal heat. Science 323: 240-244.

Borsdorf, A. 2011. Peace through climate change adaptation - innovative paths in the Biosphere Reserve Cinturón Andino, Colombia. In: Borsdorf, A., J. Stötter \& E. Veulliet (eds.), Managing Alpine Future II. International Conference 21-23 November 2011, Congress Innsbruck. Abstracts: 78. Innsbruck.

CORPOGUAJIRA - Corporación Autónoma Regional de la Guajira 2011. Plan de Manejo y Ordenamiento de la Cuenca del Rio Ranchería - POMCA del Ranchería. Guajira Colombia. http://corpoguajira.gov.co/wp/ pomca-rancheria/

DANE - Departamento Nacional de Estadística. 2012. DANE-ENA. Encuesta Nacional Agropecuaria de Colombia. Available at: https://www.dane.gov. co/index.php/agropecuario/encuesta-nacionalagropecuaria

Dougill, A.J., E.D.G. Fraser \& M.S. Reed 2010. Anticipating vulnerability to climate change in dryland pastoral systems: using dynamic systems models for the Kalahari. Ecology and Society 15(2): 17.

Emerton, L. \& H. Mogaka 1996. Participatory environmental valuation of forest resources in the Aberdares. Nai- 
robi, Kenya: CES Scoping Study Issue Paper no. 2. ICRAF. Working Paper No. 37.

Eslava, J.A. \& J.D. Pabón 2001. Proyecto: proyecciones climáticas e impactos socioeconómicos del cambio climático en Colombia. Meteorología Colombiana 3: 1-8.

Feola, G. 2013. What (science for) adaptation to climate change in Colombian agriculture? A commentary on "Away forward on adaptation to climate change in Colombian agriculture: perspectives towards 2050" by Ramirez-Villegas, J., M. Salazar, A. Jarvis, C.E. Navarro-Racines. Climatic Change 119: 565-574

FAO - Food and Agriculture Organization of the United Nations 2009. Available at: http://faostat.fao. org

Fraser, E.D.G. 2007. Travelling in antique lands: studying past famines to understand present vulnerabilities to climate change. Climate Change 83: 495-514. doi 10.1007/s10584-007-9240-9.

Gamarra-Vergara, J.R. 2006. Pobreza, corrupción y participación politica: una revisión para el caso colombiano. Serie Documentos de Trabajo Sobre Economía Regional. Banco de la República.

Gobernación de la Guajira 2012. Plan de desarrollo Departamento de la Guajira. 2012-2015. "La Guajira Primero".

Gómez-Baggethun, E., E. Corbera \& V. ReyesGarcía 2013. Traditional ecological knowledge and global environmental change: research findings and policy implications. Ecology and Society 18(4): 72. http:// dx.doi.org/10.5751/ES-06288-180472

González, M.A. \& R.L. Lopez 2007. Political Violence and Farm Household Efficiency in Colombia. Economic Development and Cultural Change 55(2): 367-392. URL: http://www.jstor.org/stable/10.1086/508715.

IDEAM - Instituto de Estudios Ambientales de Colombia 2010. Segunda Comunicación de Colombia ante el Convenio Marco de las Naciones Unidas sobre el Cambio Climático - CMNUCC. http:/ /www.pnud. org.co $/$ sitio.shtml? apc $=\mathrm{aCa} 020011--\& \mathrm{x}=62593 \#$. UyBi6_ldXO8

IPCC - Intergovernmental Panel on Climate Change. 2007. Climate change 2007: impacts, adaptation and vulnerability. In: Parry, M., O. Canziani, J. Palutikof, P. van der Linden \& C. Hanson (eds.), Working Group II contribution to the Fourth Assessment Report of the Intergovernmental Panel on Climate Change. Cambridge, UK.

Koyuncu, C. \& R. Yilmaz 2013. Deforestation, corruption and private ownership in the forest sector. Quality \& Quantity 47(1): 227-236. doi: 10.1007/ s11135-011-9513-2.

Lonin, S.A., J.L. Hernández \& D.M. Palacios 2010. Atmospheric events disrupting coastal upwelling in the southwestern Caribbean. Journal of Geophysical Research 115(C6): 17. doi:10.1029/2008JC005100, 2010.

Machovina, B. \& K.J. Feeley 2013. Climate change driven shifts in the extent and location of areas suitable for export banana production. Ecologi- cal Economics 95: 83-95. http://dx.doi.org/10.1016/j. ecolecon.2013.08.004.

Marchant, C. \& A. Borsdorf 2013. Protected areas in Northern Colombia - on track to sustainable development? eco.mont 5(2): 5-13.

Montero, L.A., L. García-Niño, R. Sánchez \& L. Abril 2011. Caracterización asimétrica de la amenaza externa colombiana. El régimen bolivariano, recursos y la aproximación indirecta. Criterio Libre 9(14): 317340.

Muggah, H.C.R. 2000. Conflict-induced Displacement and Involuntary Resettlement in Colombia: Putting Cernea's IRLR Model to the Test. Disasters 24(3): 198-216.

Polo, J. 2011. Los indígenas de la Guajira y su articulación política al Estado colombiano (1830-1880). Historia critica 44: 80-103.

Ramirez, J.A. \& J.L. Del Valle 2012. Local and global climate signals from tree rings of Parkinsonia praecox in La Guajira, Colombia. International Journal of Climatology 32: 1077-1088. doi: 10.1002/joc.2335.

Ramirez, J.A., M. Salazar, A. Jarvis \& C. NavarroRacines 2012. A way forward on adaptation to climate change in Colombian agriculture: perspectives towards 2050. Climate Change 115: 611-628.

Ramirez-Villegas, J. \& C.K. Khoury 2013. Reconciling approaches to climate change adaptation for Colombian agriculture. Climatic Change 119(3-4): 575-583. doi 10.1007/s10584-013-0792-6.

Reynolds, J.F., D.M. Stafford-Smith, E.F. Lambin, B.L. Turner, M. Mortimore, S.P.J. Batterbury, T.E. Downing, H. Dowlatabadi, R.J. Fernandez, J.E. Herrick, E. Huber-Sannwald, H. Jiang, R. Leemans, T. Lynam, F.T. Maestre, M. Ayarza \& B. Walker 2007. Global desertification: building a science for dryland development. Science 316: 847-851.

Robards, M.D., M.L. Schoon, C.L. Meek \& N.L. Engle 2011. The importance of social drivers in the resilient provision of ecosystem services. Global Environmental Change 21(2): 522-529. doi:10.1016/j. gloenvcha.2010.12.004.

Ruiz, C.A., M.L. Zárate, A.M. Cortes, C. Bello, G. Tirado, J.E. Gualdron, C.A. Riveros, R. Mariño, O. Rodríguez, J.V. Rodriguez Mahecha \& F. Arjona 2013. Hacia una economía verde en Colombia: Diseño e implementación de un esquema de Pago por Servicios Ecosistémicos (PSE) en el marco del ordenamiento territorial. Fases de diseño e implementación temprana. Caso cuenca del río Ranchería. Departamento de la Guajira - Colombia. Reflexiones sobre el Capital Natural de Colombia No. 3. Conservación Internacional Colombia. http://www.conservation.org. co/?page_id $=5746$

Santibáñez, F. \& P. Santibáñez 2007. Trends in Land Degradation in Latin America and the Caribbean, the Role of Climate Change. In: Sivakumar, M.V.K. \& N. Ndiang'ui (eds.), Climate and Land Degradation: 66-99.

Sendzimir, J., C.P. Reij \& P. Magnuszewski 2011. Rebuilding resilience in the Sahel: regreening in the 
Maradi and Zinder regions of Niger. Ecology and Society 16(3): 1. http://dx.doi.org/10.5751/ES-04198160301.

Toro, J., O. Duarte, I. Requena \& M. Zamorano 2012. Determining Vulnerability Importance in Environmental Impact Assessment The case of Colombia. Environmental Impact Assessment Review 32(1): 107-117. doi: 10.1016/j.eiar.2011.06.005.

Tovar, R.M. \& C. Irazábal 2014. Indigenous Women and Violence in Colombia Agency, Autonomy, and Territoriality. Latin American perspectives 41(1): 39-58. doi: 10.1177/0094582X13492134.

\section{Authors}

\section{Cesar Augusto Ruiz-Agudelo}

Biologist with a $\mathrm{PhD}$ in Environmental Sciences. Specialist in ecosystem services assessment and landuse planning. Currently socioeconomic manager at Conservation International (Colombia). Also profes- sor in the business school of the Universidad de los Andes in Colombia. Email: cruiz@conservation.org

\section{Oscar David Bonilla-Uribe}

Political scientist and internationalist with a Master in Environmental Management. Consultant for Conservation International and director of the C-O2 Foundation, an organization that provides corporate environmental solutions. He is an expert on climate change, environmental policy and sustainable development. Email: obonilla@c-o2.org

\section{Carlos Andres Páez}

Biologist with wide experience in the design, management and development of research projects on ecoregions, ecosystems, wildlife, biogeography and ecological integrity for the management of biodiversity and ecosystem services in Colombia. Currently ecosystem services manager at Conservation International (Colombia). 